\title{
Pemakaian Bahasa dan Penalaran sebagai Sarana untuk Menarik Kesimpulan Wacana Argumentasi
}

\author{
Margaretha Sumarwati ${ }^{1)}$ \\ Universitas Indraprasta PGRI \\ Jalan Nangka No. 58 C/TB. Simatupang, Tanjung Barat, Jakarta Selatan 12530 \\ Dendy Sugono ${ }^{2)}$ \\ Universitas Indraprasta PGRI \\ Jalan Nangka No. 58 C/TB. Simatupang, Tanjung Barat, Jakarta Selatan 12530 \\ margarethsmt78@gmail.com ${ }^{1)}$
}

\begin{abstract}
The study was conducted at SMU Ign. Slamet Riyadi, SMU Budiwarman and SMU Pangudi Rahayu East Jakarta. The purpose of this study is to describe the level of use of language as a tool to draw conclusions on the argumentation of class XI students. Semester II SMU Ign. Slamet Riyadi, SMU Budiwarman and SMU Pangudi Rahayu in East Jakarta Academic Year 2019/2020 and to describe the use of reasoning as a tool to draw discourse conclusions argumentation of class XI students in the second semester of SMU Ign. Slamet Riyadi, SMU Budiwarman and SMU Pangudi Rahayu in East Jakarta in Academic Year 2019/2020. The research instrument used in this study was in the form of a test of writing answers that drew conclusions from argumentation. Data were obtained through tests and interviews with students of class XI in the second semester of SMU Ign. Slamet Riyadi, SMU Budiwarman and SMU Pangudi Rahayu in East Jakarta in Academic Year 2019/2020 and the class teacher or accompanying teacher. The results obtained indicate that in the first test the use of language and student reasoning in drawing conclusions of argumentation discourse is still not in accordance with the wishes of researchers but in the second round test the use of language and student reasoning in drawing conclusions of argumentation discourse is good.
\end{abstract}

Keywords: Use of Language, Reasoning, Draw Conclusions, Discourse on Arguments

\begin{abstract}
Abstrak
Penelitian dilaksanakan pada SMU Ign. Slamet Riyadi, SMU Budiwarman dan SMU Pangudi Rahayu Jakarta Timur. Tujuan dari penelitian ini adalah untuk mendeskripsikan tingkat pemakaian bahasa sebagai alat untuk menarik kesimpulan wacana argumentasi siswa kelas XI.Semester II SMU Ign. Slamet Riyadi, SMU Budiwarman dan SMU Pangudi Rahayu di Jakarta Timur Tahun Ajaran 2019/2020 serta untuk mendeskripsikan pemakaian penalaran sebagai alat untuk menarik kesimpulan wacana argumentasi siswa kelas XI semester II SMU Ign. Slamet Riyadi, SMU Budiwarman dan SMU Pangudi Rahayu di Jakarta Timur Tahun Ajaran 2019/2020. Instrumen penelitian yang digunakan dalam penelitian ini berupa tes menulis jawaban menarik kesimpulan wacana argumentasi. Data diperoleh melalui tes dan wawancara kepada siswa kelas XI semester II SMU Ign. Slamet Riyadi, SMU Budiwarman dan SMU Pangudi Rahayu di Jakarta Timur Tahun Ajaran 2019/2020 dan guru kelas atau guru pendamping. Hasil penelitian yang diperoleh menyatakan bahwa pada tes pertama pemakaian bahasa dan penalaran siswa dalam penarikan kesimpulan wacana argumentasi masih belum sesuai dengan keinginan peneliti namun pada tes putaran kedua pemakaian bahasa dan penalaran siswa dalam penarikan kesimpulan wacana argumentasi sudah baik.
\end{abstract}

Kata Kunci: Pemakaian Bahasa, Penalaran, Menarik Kesimpulan, Wacana Argumentasi

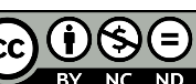

Creative Commons Attribution-NonCommercial-NoDerivatives 4.0 International License 


\section{PENDAHULUAN}

Pendidikan merupakan aspek penting bagi perkembangan sumber daya manusia, sebab pendidikan merupakan salah satu instrumen yang digunakan bukan saja untuk membebaskan manusia dari keterbelakangan melainkan juga dari kebodohan dan kemiskinan. Dunia pendidikan masa kini mengenal tiga kompetensi penting yang harus dimiliki oleh seorang siswa setelah mengalami proses pendidikan yaitu aspek kognitif (pengetahuan umum), psikomotorik (praktek), dan afektif (sikap diri). Dalam pendidikan formal, belajar menunjukan adanya perubahan yang sifatnya positif sehingga pada akhirnya akan didapat ketrampilan, kecakapan dan pengetahuan baru. Arti pendidikan itu sendiri adalah pendidikan sebagai gejala universal, merupakan suatu keharusan bagi manusia, karena selain pendidikan sebagai gejala, juga sebagai upaya memanusiakan manusia. Sistem pendidikan pada umumnya dianggap sebagai alat menyeleksi dan melatih orang untuk memegang posisi dalam suatu status pada masyarakat (Kartodirdjo, 2014:215).

Menurut Undang-Undang No. 20 Tahun 2003 tentang Sistem Pendidikan Nasional pasal 1 ayat 1 tertulis bahwa: "Pendidikan adalah usaha sadar dan terencana untuk mewujudkan suasana belajar dan proses pembelajaran agar siswa secara aktif mengembangkan potensi dirinya untuk memiliki kekuatan spiritual keagamaan, pengendalian diri, kepribadian, kecerdasan, akhlak mulia, serta keterampilan yang diperlukan dirinya, masyarakat, bangsa dan Negara".

Tujuan pendidikan nasional adalah berupaya untuk memperluas dan melakukan pemerataan pendidikan yang bermutu tinggi bagi seluruh warga negara Indonesia secara optimal. Sebagai perwujudan pencapaian tujuan tersebut, maka belajar merupakan suatu proses aktif yang memerlukan dorongan dan bimbingan agar tercapai tujuan pendidikan yang dikehendaki. Melalui pendidikan diharapkan tumbuh putra-putri bangsa Indonesia yang memiliki kepribadian tangguh dalam mendukung dan melaksanakan pembangunan nasional sesuai dengan tujuan pendidikan. Selain itu, pendidikan juga diharapkan dapat mengembangkan sikap, nilai, moral, dan ketrampilan hidup bermasyarakat dalam rangka mempersiapkan warga negara yang berkualitas.

Sekolah Menengah Umum (SMU) adalah jenjang pendidikan menengah pada pendidikan formal yang ada di Indonesia dan di dalam kurikulumnya sudah ada suatu penjurusan mata pelajaran dimulai dari kenaikan kelas XI, yaitu penjurusan untuk mata pelajaran IPA, IPS dan Bahasa. Penjurusan di SMU diperkenalkan sebagai upaya agar siswa dan siswi lebih terarah pada satu bidang yang diminatinya dan bisa lebih berkonsentrasi pada bidang yang diminati tersebut. Siswa yang mempunyai kepintaran dalam sains dan ilmu eksakta biasanya akan lebih memilih jurusan IPA sedangakan siswa yang mempunyai minat sosial dan ekonomi biasanya akan memilih jurusan IPS dan siswa yang gemar serta punya kemampuan dalam bidang bahasa maka akan memilih jurusan Bahasa. Bagi siswa yang ingin melanjutkan studi ke perguruan tinggi, Sekolah Menengah Umum (SMU) adalah sekolah yang dapat menjadi masa persiapan yang baik. Hal ini disebabkan program penjurusan biasanya dimulai di bangku Sekolah Menengah Umum (Purnama, 2010). 
Mata pelajaran Bahasa Indonesia pada kurikulum 2013 disajikan berbasis teks. Bahasa Indonesia berbasis teks menekankan pada pemahaman terhadap jenis, kaidah, dan konteks suatu teks. Dengan demikian, Bahasa Indonesia tidak hanya disampaikan sebagai pengetahuan, tetapi juga sumber aktualisasi dari penggunaan fungsinya dalam lingkup sosial (Kemdikbud, 2013:5).

Keterampilan berbahasa terdiri dari menyimak, berbicara, membaca dan menulis. Keempat keterampilan tersebut tidak dapat dipisahkan satu sama lain yang harus dikuasai oleh siswa karena merupakan ketrampilan dasar yang digunakan dalam kehidupan sehari-hari. Keterampilan membaca menduduki posisi dan peran yang penting dalam kehidupan manusia. Membaca menjadi jembatan bagi siswa yang ingin memiliki kemampuan interaktif dan terpadu. Membaca juga dianggap sebagai keterampilan berbahasa yang mudah oleh sebagian besar siswa, hal ini tidak terjadi pada keterampilan membaca pemahaman. Permasalahan awal yang muncul adalah sulitnya memahami bacaan secara keseluruhan.

Kegiatan membaca saling berhubungan dengan pola penalaran. Shadiq (2004:6) menjelaskan penalaran (jalan pikiran atau reasoning) sebagai proses berpikir yang berusaha menghubung-hubungkan fakta-fakta atau evidensi evidensi yang diketahui menuju kepada suatu kesimpulan". Secara lebih jelas, Shadiq mendefinisikan bahwa penalaran merupakan suatu kegiatan, suatu proses atau suatu aktivitas berfikir untuk menarik kesimpulan atau membuat suatu pernyataan baru yang benar berdasarkan pada beberapa pernyataan yang kebenarannya telah dibuktikan atau diasumsikan sebelumnya. Membaca dan pola penalaran itu saling berkaitan erat, membaca bukan hanya sekadar membaca, tetapi merupakan suatu kegiatan yang terorganisir sedemikian rupa, sehingga terjadi suatu penalaran yang dapat menghasilkan sebuah ide/gagasan yang baik. Proses bernalar atau singkatnya penalaran merupakan proses berpikir yang sistematik untuk memperoleh kesimpulan berupa pengetahuan. Dari prosesnya, penalaran itu dapat dibedakan sebagai penalaran induktif dan deduktif.

Dalam penelitian ini, siswa diharapkan dapat menarik kesimpulan untuk menyajikan dan mempengaruhi pendapat orang lain dengan menyodorkan pikiran kritis dan logis melalui bukti-bukti yang relevan dengan tujuannya (Sujanto, 1998:36). Namun fenomena yang terjadi siswa-siswi SMU masih belum mampu mengembangkan pemakaian bahasa dan penalaran sebagai alat untuk menarik simpulan. Sebagaimana yang terjadi di siswa kelas XI SMU Ign.Slamet Riyadi, SMU Budiwarman dan Pangudi Rahayu ketika penulis melakukan penelitian dan memberikan soal pendahuluan Wacana argumentasi tentang "Mencegah Penyalahgunaan Obat". Siswa masih belum dapat memahami isi teks sepenuhnya sehingga siswa mengalami kesulitan ketika harus menarik kesimpulan.

Faktor yang mempengaruhi penarikan kesimpulan wacana argumentasi adalah pemakaian bahasa. Siswa masih belum bisa menggunakan bahasa yang baik dan teratur sehingga sulit dipahami maksudnya. Siswa juga belum bisa memahami secara jelas makna dari teks yang siswa baca sehingga ketika menarik kesimpulan bahasa yang digunakan belum tertata dengan baik, baik secara induktif maupun secara deduktif bahkan ada sebagian kesimpulan yang tidak teridentifikasi. Faktor lainnya dalam penarikan kesimpulan wacana argumentasi adalah penalaran siswa 
yang masih rendah sehingga jawaban mereka kurang sesuai dengan pertanyaan yang diberikan.

Penalaran mempunyai peran yang cukup penting dalam penarikan kesimpulan wacara argumentasi yaitu penalaran yang menggunakan pikiran sudah tentu berpangkal pada logika sehingga dapat diperoleh hubungan antar pernyataan. Ketika siswa tidak memiliki penalaran yang bagus maka hasil penarikan kesimpulan yang diberikan pun tidak bagus atau tidak sesuai dengan yang diharapkan.

Kemampuan membaca merupakan kemampuan menangkap inti suatu bacaan dan merumuskan pengetahuan dan pemahaman yang dimiliki minimal dalam bahasa tulis (Winkel, 2012:88), sedangkan menurut Tarigan (2008:36) kemampuan membaca merupakan suatu keterampilan yang kompleks yang melibatkan keterampilan pengenalan huruf, pengenalan unsur-unsur lingustik, dan keterampilan yang bersifat pemahaman.

Membaca pada hakikatnya adalah suatu yang rumit yang melibatkan banyak hal, tidak hanya sekedar melafalkan tulisan, tetapi juga melibatkan aktivitas visual, berpikir, psikolinguistik, dan metakognitif. Menurut pandangan tersebut, membaca sebagai aktivitas visual merupakan proses menerjemahkan simbol tulis ke dalam bunyi. Sebagai suatu aktivitas berpikir, membaca mencakup pengenalan kata, pemahaman literal, interpretasi, membaca kritis (critical reading), dan membaca kreatif (creative reading). Membaca sebagai proses linguistik, skemata pembaca membantunya membangun makna, sedangkan fonologis, semantik, dan fitur sintaksis membantunya mengkomunikasikan dan menginterpretasikan pesanpesan.

Menurut Keraf (2010:3), argumentasi merupakan suatu bentuk retorika yang berurutan untuk mempengaruhi sikap dan pendapat orang lain agar percaya dan akhirnya bertindak sesuai dengan keinginan penulis. Usaha tersebut dilakukan dengan mengajukan bukti-bukti, fakta-fakta yang benar dan merangkaikan penutur secara logis menuju pada suatu kesimpulan yang dapat dipertanggungjawabkan.

Penarikan kesimpulan merupakan hasil akhir dari suatu penelitian, sehingga penelitian yang mula-mula belum jelas meningkat menjadi lebih jelas dan rinci. Menurut Suliyanto (2006) kesimpulan merupakan bagian akhir tulisan yang membawa pembaca keluar dari pembahasan. Secara umum kesimpulan menunjukan jawaban atas tujuan yang telah dikemukakan dalam pendahuluan.

Kemampuan menulis merupakan salah satu keterampilan berbahasa yang diajarkan di sekolah. Menulis merupakan bagian yang tidak terpisahkan dalam seluruh proses belajar yang dialami oleh pelajar dan mahasiswa karena kegiatan menulis akan memperluas wawasan tentang suatu topik yang ditulis oleh seluruh pelajar dan mahasiswa (Akhadiah, dkk., 2012:1). Suatu kalimat akan mudah dipahami jika didukung oleh tata bahasa yang baik. Bagaimana kata yang dipergunakan dalam kalimat baku atau tidak baku. Kalimat yang dipergunakan harus efektif dan efisien, serta mempunyai struktur yang benar. Menurut Santrock (2009:8) penalaran adalah pemikiran logis yang menggunakan induksi dan deduksi untuk mencapai sebuah kesimpulan.

Jenis-jenis penalaran meliputi penalaran deduktif dan penalaran induktif. Deduksi berasal dari bahasa bahasa inggris deduction yang berarti penarikan 
kesimpulan dari keadaan-keadaan yang umum, menemukan yang khusus dari yang umum, lawannya induksi (Poerwadarminta, 2006:237). Penalaran deduktif adalah penarikan kesimpulan berdasarkan aturan yang telah disepakati yang bertolak dari hal-hal yang bersifat umum kepada hal-hal yang bersifat khusus (Sumarmo, 2010:5).

Menurut Sumarmo (2010:5) indikator penalaran deduktif diantaranya adalah: Memahami masalah; Merencanakan perhitungan berdasarkan aturan atau rumus tertentu; Melaksanakan perhitungan berdasarkan aturan atau rumus tertentu; Menarik kesimpulan secara deduktif. Dalam penelitian ini indikator penalaran deduktif yang digunakan oleh peneliti adalah menarik kesimpulan.

Penalaran induktif adalah penarikan kesimpulan yang bertolak dari hal-hal yang khusus atau spesifik ke hal-hal yang bersifat umum (Sumarmo, 2010:5). Penalaran induktif merupakan proses berpikir untuk menarik kesimpulan tentang hal umum yang berpijak pada hal khusus (Haryono dan Tanujaya, 2018:128). Adapun macam-macam penalaran induktif, yaitu: Penalaran Analogi, adalah Salah satu metode untuk bernalar adalah dengan menggunakan analogi. Analogi adalah berbicara tentang suatu hal yang berlainan, dan dua hal yang berlainan lalu dibandingkan. Penalaran analogi merupakan penalaran induktif dengan membandingkan dua hal yang banyak persamaannya. (Soekardjo, 1999:27). Generalisasi adalah suatu proses penalaran yang bertolak dari sejumlah fenomena individual (khusus) menuju kesimpulan umum yang mengikat seluruh fenomena sejenis dengan fenomena individual yang diselidiki.

Menurut Sumarmo (2010:8) indikator penalaran induktif diantaranya adalah: Menentukan strategi mencoba-coba untuk menyelesaikan masalah; Menyelesaikan masalah dengan cara mencoba-coba; Penarikan kesimpulan umum berdasarkan sejumlah data yang teramati; Penarikan kesimpulan berdasarkan keserupaan data, konsep, atau proses. Dalam penelitian ini indikator penalaran induktif yang digunakan oleh peneliti adalah penarikan kesimpulan.

Secara umum, Tarigan (2008:7) membatasi pengertian membaca sebagai suatu proses yang dilakukan serta digunakan oleh pembaca untuk memperoleh pesan yang hendak disampaikan oleh penulis melalui kata-kata atas bahasa tulis. Adapun tujuan utama dalam membaca adalah untuk mencari serta memperoleh informasi, mencakup isi, memahami makna bacaan. Makna, arti (meaning) berkaitan erat dengan maksud, tujuan, atau intensitas kita dalam membaca (Tarigan, 2008:9).

\section{METODE}

Metode penelitian yang digunakan dalam penelitian ini adalah metode penelitian deskriptif kualitatif. Sugiyono (2017:9) mengemukakan penelitian kualitatif sebagai metode penelitian yang berlandaskan pada filsafat postpositivisme, digunakan untuk meneliti pada kondisi objek alamiah, dimana peneliti adalah sebagai instrumen kunci, teknik pengumpulan data dengan triangulasi, analisis data bersifat induktif atau kualitatif, dan hasil penelitian kualitatif lebih menekankan makna daripada generalisasi.

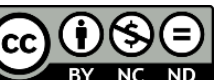

Creative Commons Attribution-NonCommercial-NoDerivatives 4.0 International License 
Subjek dalam penelitian ini adalah siswa kelas XI semester II SMU Ign. Slamet Riyadi, SMU Budiwarman dan SMU Pangudi Rahayu tahun ajaran 2019/2020. Jumlah subyek penelitian dari kelas XI semester II ini adalah 500 siswa yang terdiri dari 12 kelas yaitu SMU Ign. Slamet Riyadi sebanyak 3 kelas, SMU Budiwarman ada 7 kelas dan SMU Pangudi Rahayu ada 2 kelas.

Partisipan adalah semua orang atau manusia yang berpatisipasi atau ikut serta dalam suatu kegiatan. Menurut pandangan dari Hetifah \& Sumarto (2003:17) partisipan yaitu "Pengambilan bagian atau keterlibatan orang atau masyarakat dengan cara memberikan dukungan (tenaga, pikiran maupun materi) dan tanggung jawabnya terhadap setiap keputusan yang telah diambil demi tercapainya tujuan yang telah ditentukan bersama".

Dalam penelitian ini peneliti melibatkan beberapa pastisipan yaitu:

1. Siswa kelas XI semester II SMU Ign. Slamet Riyadi tahun ajaran 2019/2020.

2. Siswa kelas XI semester II SMU Budiwarman tahun ajaran 2019/2020.

3. Siswa kelas XI semester II SMU Pangudi Rahayu tahun ajaran 2019/2020.

4. Guru kelas atau guru pendamping dari SMU Ign. Slamet Riyadi, SMU Budiwarman dan SMU Pangudi Rahayu.

Jumlah responden yang diteliti dalam penelitian ini sebanyak 100 orang dengan perincian 84 siswa yang diberikan tes, 12 siswa yang diwawancarai dan 4 guru kelas (pendamping) yang diwawancarai.

Dalam penelitian ini instrumen yang digunakan antara lain: dokumentasi, observasi, dan wawancara. Instrumen dokumentasi adalah alat bantu yang digunakan untuk mengumpulkan data-data yang berupa dokumen seperti instrumen tes. Instrumen tes yang digunakan dalam penelitian ini adalah tes wacana argumentasi (mencegah penyalahgunaan obat). Penilaian dari hasil tes ini berdasarkan kemampuan siswa dalam menarik kesimpulan wacana argumentasi. Tes yang dibuat untuk mengetahui kemampuan siswa dalam pemakain bahasa dan penalaran sebagai alat untuk menarik kesimpulan wacana argumentasi. Instrumen observasi merupakan pedoman peneliti dalam mengadakan pengamatan dan pencarian sistematik terhadap fenomena yang diteliti. Pedoman ini berkaitan dengan situasi dan kondisi di SMU Ign. Slamet Riyadi, SMU Budiwarman dan SMU Pangudi Rahayu. Wawancara ini dilakukan pada guru kelas atau guru pendamping dan juga siswa kelas XI dari SMU Ign. Slamet Riyadi, SMU Budiwarman, dan SMU Pangudi Rahayu Jakarta Timur.

Teknik analisis data yang digunakan dalam penelitian ini melalui reduksi data, penyajian data, dan menarik simpulan.

\section{HASIL PENELITIAN DAN PEMBAHASAN}

\section{Hasil}

\section{Pemakaian Bahasa sebagai alat untuk Menarik Kesimpulan Wacana Argumentasi}

1. Deskripsi Penilaian 
Data penelitian ini berupa tulisan hasil pemakaian bahasa sebagai alat untuk menarik kesimpulan wacana argumentasi yang diperoleh dari sampel kelas XI yang siswa kelas XI Semester II SMU Budiwarman Tahun Ajaran 2019/2020. Setiap tulisan yang siswa buat diberi penilaian yang kemudian dikelompokkan. Untuk memudahkan pengelompokan, maka tulisan hasil pemakaian bahasa ini disusun dengan cara membuat tabulasi dan kemudian menghitung frekuensi sementara masing-masing skor. Distribusi frekuensi dalam penilaian ini disusun dalam bentuk tabel distribusi tunggal dari sampel kelas XI. Penyusunan distribusi frekuensi ke dalam bentuk tabel sebagai berikut.

\section{Tabel 1. Distribusi Frekuensi Skor Pemakaian Bahasa Sebagai Alat Untuk Menarik Kesimpulan Wacana Argumentasi Siswa Kelas XI SMU Pangudi Rahayu Tahun Ajaran 2019/2020}

\begin{tabular}{ccccc}
\hline No & Skor & Frekuensi (f) & Persentase $(\%)$ & Keterangan \\
\hline 1 & $96-100$ & 0 & $0,0 \%$ & - \\
2 & $86-95$ & 0 & $0,0 \%$ & - \\
3 & $76-85$ & 6 & $20,0 \%$ & Baik \\
4 & $66-75$ & 8 & $26,7 \%$ & Cukup Baik \\
5 & $56-65$ & 16 & $53,3 \%$ & Sedang \\
6 & $46-55$ & 0 & $0,0 \%$ & - \\
7 & $36-45$ & 0 & $0,0 \%$ & - \\
8 & $26-35$ & 0 & $0,0 \%$ & - \\
9 & $16-25$ & 0 & $0,0 \%$ & - \\
10 & $0-15$ & 0 & $0,0 \%$ & - \\
& Total & $\mathbf{3 0}$ & $\mathbf{1 0 0}$ & - \\
\hline
\end{tabular}

Berdasarkan tabel di atas dapat dijelaskan bahwa pada pengujian dilakukan di SMU Pangudi Rahayu Jakarta Timur. Hal ini dilakukan karena SMU Pangudi Rahayu mempunyai siswa yang paling sedikit di antara SMU Ign. Slamet Riyadi dan SMU Budiwarman. Hasil yang diperoleh adalah sebagian besar siswa mendapatkan nilai pada rentang antara 56--65 yang termasuk dalam kategori sedang. Pada pengujian ini peneliti merasa pemakaian bahasa dalam penarikan kesimpulan wacana argumentasi belum berhasil, karena masih banyak siswa yang belum memahami perintahnya dan terdapat beberapa coretan, oleh karena itu peneliti merevisi soal, wacana dan memperbaiki bentuk pertanyaan. Setelah soal, wacana dan bentuk pertanyaan direvisi kemudian digunakan untuk pengujian putaran kedua.

2. Deskripsi Penghitungan Nilai Rata-Rata

Setelah data diolah dan disusun ke dalam tabel-tabel distribusi frekuensi, maka langkah selanjutnya adalah menghitung jumlah skor pengujian pertama. Pada pengujian pertama jumlah responden berjumlah 30 siswa dengan skor sebagai berikut. 
Tabel 2. Penghitungan Rata-Rata Jumlah Skor Kelas XI SMU Pangudi Rahayu Tahun Ajaran 2019/2020

\begin{tabular}{|c|c|c|c|c|c|}
\hline No & Skor $(\mathrm{X})$ & Frekuensi(f) & $\mathbf{F}(\mathbf{X})$ & Persentase & Keterangan \\
\hline 1. & 10 & 0 & 0 & $0,0 \%$ & - \\
\hline 2. & 9 & 0 & 0 & $0,0 \%$ & - \\
\hline 3. & 8 & 6 & 48 & $20,0 \%$ & Baik \\
\hline 4. & 7 & 8 & 56 & $26,7 \%$ & Cukup Baik \\
\hline 5. & 6 & 16 & 96 & $53,3 \%$ & Sedang \\
\hline 6. & 5 & 0 & 0 & $0,0 \%$ & - \\
\hline 7. & 4 & 0 & 0 & $0,0 \%$ & - \\
\hline 8. & 3 & 0 & 0 & $0,0 \%$ & - \\
\hline 9. & 2 & 0 & 0 & $0,0 \%$ & - \\
\hline 10. & 1 & 0 & 0 & $0,0 \%$ & - \\
\hline \multicolumn{2}{|c|}{ Total } & 30 & 200 & 100 & - \\
\hline & & $\begin{array}{r} \\
\bar{X}= \\
\bar{X}=- \\
\bar{X}=0,66\end{array}$ & $\begin{array}{l}\frac{\sum X}{N} \\
0=6, \\
=0, \\
100\end{array}$ & 76 & \\
\hline
\end{tabular}

Rahayu Tahun Ajaran 2019/2020 pada pengujian pertama diperoleh nilai sebesar 66,7 atau $66,7 \%$. Nilai tersebut masuk dalam interval persentase tingkat penguasaan antara 66\%--75\%, untuk nilai ubahan skala sepuluh adalah 7 sehingga dapat dikategorikan kedalam kriteria cukup baik.

Selanjutnya dilakukan pengujian kedua yaitu pada sampel penelitian yang berjumlah 84 orang siswa. Sampel ini diambil dari siswa kelas XI dari SMU Ign. Slamet Riyadi dan SMU Budiwarman Jakarta Timur. Pertanyaan yang diberikan adalah pertanyaan tentang menarik kesimpulan wacana argumentasi "mencegah penyalahgunaan obat" yang merupakan pertanyaan pada pengujian pertama yang telah direvisi oleh peneliti dan dosen pembimbing. Pertanyaan yang telah direvisi ini diharapkan dapat dipahami oleh para siswa dalam menarik kesimpulan wacana argumentasi, sehingga siswa dapat menjawab pertanyaan-pertanyaan tersebut dengan lebih baik.

Tabel 3. Distribusi Frekuensi Skor Pemakaian Bahasa Sebagai Alat

Untuk Menarik Kesimpulan Wacana Argumentasi Siswa Kelas XI SMU Ign. Slamet Riyadi dan SMU Budiwarman Tahun Ajaran 2019/2020

\begin{tabular}{ccccc}
\hline No & Skor & Frekuensi (f) & Persentase $(\%)$ & Keterangan \\
\hline 1 & $96-100$ & - & - & - \\
2 & $86-95$ & 22 & $26,2 \%$ & Baik Sekali \\
3 & $76-85$ & 49 & $58,3 \%$ & Baik
\end{tabular}




\begin{tabular}{ccccc}
4 & $66-75$ & 13 & $15,5 \%$ & Cukup Baik \\
5 & $56-65$ & - & - & - \\
6 & $46-55$ & - & - & - \\
7 & $36-45$ & - & - & - \\
8 & $26-35$ & - & - & - \\
9 & $16-25$ & - & - & - \\
10 & $0-15$ & - & - & - \\
& Total & $\mathbf{8 4}$ & $\mathbf{1 0 0}$ & - \\
\hline
\end{tabular}

Berdasarkan tabel di atas dapat dijelaskan bahwa pada pengujian kedua dilakukan pada 84 siswa yang diambil dari SMU Ign. Slamet Riyadi dan SMU Budiwarman Jakarta Timur. Sampel diambil berdasarkan persentase dari jumlah siswa masing-masing sekolah. Jumlah sampel paling banyak diambil dari SMU Budiwarman yaitu sebanyak 50 siswa dan diikuti oleh SMU Ign. Slamet Riyadi sebanyak 34 siswa. Hasil pengujian yang diperoleh mengalami peningkatan dibandingkan dengan pengujian pertama. Hal ini menunjukkan bahwa siswa kelas XI semester II SMU Ign. Slamet Riyadi dan SMU Budiwarman di Jakarta Timur Tahun Ajaran 2019/2020 mampumemahami pertanyaan yang diberikan dan mampu menjawab dengan baik tentang menarik kesimpulan wacana argumentasi "mencegah penyalahgunaan obat".

Tabel 4. Penghitungan Rata-Rata Jumlah Skor Kelas XI SMU Ign. Slamet Riyadi dan SMU Budiwarman Tahun Ajaran 2019/2020

\begin{tabular}{cccccc}
\hline No & Skor $(\mathbf{X})$ & Frekuensi(f) & $\mathbf{F}(\mathbf{X})$ & Persentase & Keterangan \\
\hline 1. & 10 & 0 & 0 & $0,0 \%$ & - \\
2. & 9 & 22 & 198 & $0,0 \%$ & Baik Sekali \\
3. & 8 & 49 & 392 & $20,0 \%$ & Baik \\
4. & 7 & 13 & 91 & $26,7 \%$ & Cukup Baik \\
5. & 6 & 0 & 0 & $0,0 \%$ & - \\
6. & 5 & 0 & 0 & $0,0 \%$ & - \\
7. & 4 & 0 & 0 & $0,0 \%$ & - \\
8. & 3 & 0 & 0 & $0,0 \%$ & - \\
9. & 2 & 0 & 0 & $0,0 \%$ & - \\
10. & 1 & 0 & 0 & $0,0 \%$ & - \\
& Total & $\mathbf{8 4}$ & $\mathbf{6 8 1}$ & $\mathbf{1 0 0}$ & - \\
\hline
\end{tabular}

$$
\begin{gathered}
\bar{X}=\frac{\sum X}{N} \\
\bar{X}=\frac{681}{84}=8,11 \\
\bar{X}=\frac{8,11}{10}=0,811
\end{gathered}
$$




$$
\overline{\mathrm{X}}=0,811 * 100=81,1
$$

Berdasarkan perhitungan rata-rata jumlah skor Kelas XI dari ketiga sekolah menengah umum yang dijadikan sampel penelitian yaitu SMU Ign. Slamet Riyadi dan SMU Pangudi Budiwarman Ajaran 2019/2020 pada pengujian kedua diperoleh nilai sebesar 81,1 atau $81,1 \%$. Nilai tersebut masuk dalam interval persentase tingkat penguasaan antara $76 \%-85 \%$, untuk nilai ubahan skala sepuluh adalah 8 sehingga dapat dikategorikan ke dalam kriteria baik.

\section{Analisis Data Penggunaan Penalaran dalam Menarik Kesimpulan Wacana Argumentasi}

Subjek penelitian dalam penelitian ini diambil dari siswa kelas XI dari tiga sekolah yaitu SMU Ign. Slamet Riyadi dan SMU Budiwarman semuanya berjumlah 84 siswa. Ada beberapa kemungkinan penalaran dalam menarik kesimpulan pada siswa yang menjadi sampel tersebut. Penalaran siswa tersebut terdeskripsi dalam data yang berupa jawaban-jawaban siswa hasil pemakaian bahasa sebagai alat untuk menarik kesimpulan wacana argumentasi baik pada setiap subwacana maupun satuwacana. Kemungkinan penalaran ada yaitu secara induktif, deduktif, dan ada yang tidak teridentifikasi. Secara rinci dapat dijabarkan sebagai berikut.

Tabel 5. Penggunaan Penalaran dalam Menarik Kesimpulan Wacana argumentasi Siswa Kelas XI SMU Ign. Slamet Riyadi dan SMU Budiwarman Tahun Ajaran 2019/2020

\begin{tabular}{clccc}
\hline No. & $\begin{array}{c}\text { Subwacana/Seluruh } \\
\text { Subwacana }\end{array}$ & Induktif & Deduktif & $\begin{array}{c}\text { Tidak } \\
\text { Teridentifikasi }\end{array}$ \\
\hline 1. & Subwacana 1 & 82 & 2 & - \\
2. & Subwacana 2 & 78 & 5 & 1 \\
3. & Subwacana 3 & 12 & 68 & 4 \\
4. & Subwacana 4 & 45 & 32 & 7 \\
5. & Seluruh Subwacana & 17 & 59 & 8 \\
& Jumlah & $\mathbf{2 3 4}$ & $\mathbf{1 6 6}$ & $\mathbf{2 0}$ \\
\hline
\end{tabular}

Berdasarkan tabel di atas dapat dijelaskan bahwa dari 84 siswa Kelas XI SMU Ign. Slamet Riyadi, dan SMU Budiwarman Tahun Ajaran 2019/2020 diberikan soal tes untuk menarik kesimpulan wacana argumentasi tentang "Mencegah Penyalahgunaan Obat". Wacana argumentasi tersebut terdiri dari 4 subwacana dan 1 wacana keseluruhan. Pada subwacana 1, subwacana 2 dan subwacana 4 sebagian besar siswa menggunakan penalaran induktif dan hanya pada subwacana 2 dan subwacana 4 terdapat jawaban siswa yang tidak teridentifikasi sebanyak 8 jawaban. Sedangkan pada subwacana 3 dan wacana sebagian besar siswa menggunakan penalaran deduktif dan hanya pada subwacana 3 dan wacana 4 terdapat jawaban siswa yang tidak teridentifikasi sebanyak 12 jawaban. Jadi dapat disimpulkan bahwa penggunaan penalaran dalam menarik kesimpulan wacana argumentasi pada siswa kelas XI SMU Ign. Slamet Riyadi, dan SMU Budiwarman 
Tahun Ajaran 2019/2020 sebagian besar menggunakan penalaran induktif.

\section{Pembahasan}

\section{Pemakaian Bahasa Sebagai Alat Untuk Menarik Kesimpulan Wacana Argumentasi}

Proses pelaksanaan di lapangan tentang pemakaian bahasa, peneliti memberikan sebuah tulisan berupa wacana argumentasi tentang mencegah penyalahgunaan obat. Siswa diminta untuk menarik kesimpulan dari wacana argumentasi tersebut. Pemakaian Bahasa Indonesia yang baik dan benar adalah penting sekali dalam penarikan kesimpulan wacana argumentasi karena hasil kesimpulan yang ditulis akan dapat dengan mudah dimengerti dan dipahami maksudnya.

Pengujian pertama dilakukan pada 30 siswa kelas XI semester II SMU Pangudi Rahayu Jakarta Timur. Mereka menjawab tes esai secara tertulis dalam bentuk kalimat/paragraf yang terdiri atas 1 sampai 5 kalimat tentang wacana argumentasi mencegah penyalahgunaan obat. Skala atau ukuran nilai ditentukan antara 1 sampai 10. Skor yang diperoleh berkisar antara 60 (5) sampai 78 (8), dengan nilai rata-rata 66,7 dengan nilai ubahan sepuluh adalah 7 . Jika dipersentasekan menjadi $66,7 \%$. Nilai rata-rata tersebut digolongkan ke dalam kriteria cukupbaik.Secara rinci dapat diperjelas dengan tabel sebagai berikut.

Tabel 6. Tingkat Pemakaian Bahasa sebagai Alat untuk Menarik Kesimpulan Wacana Argumentasi Siswa Kelas XI SMU Pangudi Rahayu Tahun Ajaran 2019/2020

\begin{tabular}{cclc}
\hline $\begin{array}{c}\text { IntervalPersentase } \\
\text { Tingkat } \\
\text { Kemampuan }\end{array}$ & $\begin{array}{c}\text { Nilai Ubahan } \\
\text { Skala Sepuluh }\end{array}$ & $\begin{array}{c}\text { Tingkat } \\
\text { Kemampuan } \\
\text { Kelas XI }\end{array}$ & Keterangan \\
\hline $96 \%-100 \%$ & 10 & & Sempurna \\
$86 \%-95 \%$ & 9 & & Baik Sekali \\
$76 \%-85 \%$ & 8 & Baik \\
$66 \%-75 \%$ & 7 & Pemakat & Cukup Baik \\
& & Bahasa siswa & \\
& & Kelas XI SMU & \\
& & Pangudi & Rahayu \\
$56 \%-65 \%$ & 6 & & Sedang \\
$46 \%-55 \%$ & 5 & & Kampir Sedang \\
$36 \%-45 \%$ & 4 & & Kurang \\
$26 \%-35 \%$ & 3 & & Buruk \\
$16 \%-25 \%$ & 2 & & Buruk Sekali \\
$0 \%-15 \%$ & 1 & & \\
\hline
\end{tabular}

Melihat deskripsi perhitungan nilai rata-rata dan penentuan patokan dengan persentase untuk skala sepuluh maka dapat disimpulkan bahwa siswa Kelas XI 
Semester II SMU Pangudi Rahayu Tahun Ajaran 2019/2020 mempunyai tingkat pemakaian bahasa sebagai alat untuk menarik wacana argumentasi dalam kriteria cukup baik. Di satu sisi ada hal-hal menarik yang perlu disimak jika kita kembali melihat data-data yang telah dijelaskan sebelumnya adalah interval skor dalam penyebarannya dapat dikatakan hampir merata dan hampir runtut dari skor minimal 1 hingga skor maksimal 10. Jarak sebaran antara satu skor dengan skor berikutnya berkisar antara 1. Hal ini karena nilai dikelompokkan dalam interval sehingga nilai yang satu dengan nilai yang lainnya bisa berada dalam satu skor, misalnya interval persentase 66\%--75\% berada pada skor 7. Artinya bahwa apabila siswa mendapatkan nilai 66--75 berada pada skor 7 .

Untuk sampel penelitian diambil dari kelas XI SMU Ign. Slamet Riyadi dan SMU Budiwarman berjumlah 84 siswa. Sama seperti pada pengujian pertama, pengujian kedua ini juga mereka menjawab tes esai secara tertulis dalam bentuk kalimat/paragraf yang terdiri atas 1 sampai 5 kalimat tentang wacana argumentasi mencegah penyalahgunaan obat. Namun, sebelumnya peneliti memperbaiki bentuk pertanyaan dan menghilangkan coretan dalam wacana. Skala atau ukuran nilai ditentukan antara 1 sampai 10. Skor yang diperoleh berkisar antara 71 (7) sampai 96 (10), dengan nilai rata-rata 81,1 dengan nilai ubahan sepuluh adalah 8. Jika dipersentasekan menjadi $81,1 \%$. Nilai rata-rata tersebut digolongkan ke dalam kriteria baik.Secara rinci dapat diperjelas dengan tabel sebagai berikut.

Tabel 7. Tingkat Pemakaian Bahasa sebagai Alat untuk Menarik Kesimpulan Wacana Argumentasi Siswa Kelas XI SMU Ign. Slamet Riyadi dan SMU Budiwarman Tahun Ajaran 2019/2020

\begin{tabular}{|c|c|c|c|}
\hline $\begin{array}{l}\text { Interval Persentase } \\
\text { Tingkat Kemampuan }\end{array}$ & $\begin{array}{l}\text { Nilai Ubahan } \\
\text { Skala Sepuluh }\end{array}$ & $\begin{array}{c}\text { Tingkat } \\
\text { Kemampuan } \\
\text { Kelas XI }\end{array}$ & Keterangan \\
\hline $96 \%-100 \%$ & 10 & & Sempurna \\
\hline $86 \%-95 \%$ & 9 & & Baik Sekali \\
\hline $76 \%-85 \%$ & 8 & $\begin{array}{l}\text { Tingkat } \\
\text { Pemakaian } \\
\text { Bahasa siswa } \\
\text { Kelas XI SMU } \\
\text { Ign. Slamet } \\
\text { Riyadi dan SMU } \\
\text { Budiwarman }\end{array}$ & Baik \\
\hline $66 \%-75 \%$ & 7 & & Cukup Baik \\
\hline $56 \%-65 \%$ & 6 & & Sedang \\
\hline $46 \%-55 \%$ & 5 & & Hampir Sedang \\
\hline $36 \%-45 \%$ & 4 & & Kurang \\
\hline $26 \%-35 \%$ & 3 & & Kurang Sekali \\
\hline $16 \%-25 \%$ & 2 & & Buruk \\
\hline $0 \%-15 \%$ & 1 & & Buruk Sekali \\
\hline
\end{tabular}

Melihat hasil pengujian kedua menunjukkan bahwa rata-rata siswa dari SMU Ign. Slamet Riyadi dan SMU Budiwarman Jakarta Timur telah memahami 
pemakaian bahasa sebagai alat untuk menarik kesimpulan wacana argumentasi. Hal ini dibuktikan dengan nilai rata-rata yang diperoleh sebesar $81,1 \%$ yang masuk dalam kriteria baik. Jadi dengan memperbaiki soal dan wacana yang diujikan pada pengujian pertama, siswa lebih dapat memahami pemakaian bahasa sebagai alat untuk menarik kesimpulan wacana argumentasi.

Hasil wawancara dengan guru kelas atau guru pendamping menyatakan bahwa siswa memang belum bisa menggunakan bahasa secara baik dan benar dalam penarikan kesimpulan karena siswa belum pernah diberi soal terkait penarikan kesimpulan wacana argumentasi. Namun, siswa baru diajarkan tentang karangan deskripsi, narasi dan eksposisi sehingga ketika pertama kali siswa diberi pertanyaan tentang penarikan kesimpulan wacana argumentasi siswa kurang memahaminya, tetapi setelah dilakukan tes kedua siswa sudah dapat memahami sehingga jawaban yang diberikan juga sudah cukup bagus dibandingkan dengan jawaban pertama. Jadi, sebenarnya siswa akan dapat mengerti apa pun jika mereka sering diberi pembelajaran dan pelatihan.

Begitu juga hasil wawancara dengan beberapa siswa, mereka mengatakan bahwa siswa benar-benar belum bisa memahami tentang wacana argumentasi sehingga ketika harus menarik kesimpulan siswa belum memahami isi tulisan dari masing-masing paragraf sehingga jawaban yang mereka berikan sangat jauh dari yang diinginkan peneliti. Pemakaian bahasa yang siswa gunakan juga masih belum bagus dan belum teratur sehingga tidak jelas maksudnya. Sebagian besar siswa hanya membaca tanpa memahami apa isi teks yang dibacanya.

Hasil penelitian ini sesuai dengan hasil penelitian yang dilakukan oleh Sunarti (2002) yang meneliti tentang kemampuan siswa kelas II SLTP Yos Sudarso, Cigugur, Kuningan, dengan jenis karangan argumentasi. Nugraheni (2002) yang meneliti tentang kemampuan siswa kelas II SMU Negeri Pakem dalam membuat paragraph deskripsi. Hasil yang diperoleh dari kedua penelitian tersebut menyatakan bahwa tingkat kemampuan menulis baik karangan argumentasi maupun karangan deskripsi sudah cukup baik.

Jadi, dapat disimpulkan bahwa pemakaian bahasa sebagai alat untuk menarik kesimpulan wacana argumentasi pada Kelas XI SMU Ign. Slamet Riyadi, SMU Budiwarman dan SMU Pangudi Rahayu Tahun Ajaran 2019/2020 sudah termasuk cukup baik dan setelah dilakukan pengujian kedua siswa telah memahami pemakaian bahasa sebagai alat untuk menarik kesimpulan wacana argumentasi dan hasil pengujiannya sudah baik.

\section{Pemakaian penalaran sebagai alat untuk menarik kesimpulan wacana argumentasi}

Sama seperti pada pemakaian bahasa sebagai alat untuk menarik kesimpulan wacana argumentasi, proses pelaksanaan di lapangan tentang pemakaian penalaran, peneliti memberikan sebuah tulisan berupa wacana argumentasi tentang mencegah penyalahgunaan obat. Siswa diminta untuk menarik kesimpulan dari wacana argumentasi tersebut. Penalaran bahasa penting sekali dalam menarik kesimpulan wacana argumentasi karena karena akan meningkatkan kemampuan literasi bahasa. Kemampuan penalaran bahasa siswa ditingkatkan melalui pemberian tugas-tugas yang dapat melatih penalaran siswa. Melalui tugas 
yang diberikan, siswa akan terlatih menggunakan penalarannya, sehingga dapat meningkatkan kemampuan literasi bahasa.

Tuntutan kemampuan siswa dalam bahasa tidak sekedar memiliki kemampuan membaca saja, akan tetapi kemampuan bernalar yang logis dan kritis dalam pemecahan masalah. Pemecahan masalah ini tidak semata-mata masalah yang berupa soal rutin akan tetapi lebih kepada permasalahan yang dihadapi seharihari.

Wacana argumentasi yang berjudul "Mencegah Penyalahgunaan Obat" terdiri dari 4 subwacana ditambah 1 subwacana secara keseluruhan (wacana). Setiap subwacana dapat ditarik kesimpulan. Siswa dapat menarik kesimpulan dari subwacana 1, subwacana 2, subwacana 3, subwacana 4, dan dilanjutkan dengan menarik kesimpulan satu wacana (secara keseluruhan). Dari data-data yang diperoleh, ternyata ditemukan cara berpikir mereka. Penalaran mereka dalam menarik kesimpulan subwacana dan satu wacana (sub wacana 1, 2, 3, 4), sebagian menggunakan penalaran secara induktif, sebagian menggunakan penalaran secara deduktif, dan sebagian lagi tidak teridentifikasi. Dari ketiga penalaran tersebut penalaran secara induktif yang paling banyak digunakan diikuti oleh penalaran deduktif dan sebagian lagi tidak teridentifikasi.

Sampel keseluruhan Kelas XI SMU Ign. Slamet Riyadi dan SMU Budiwarman Tahun Ajaran 2019/2020 berjumlah 84 siswa. Dari 84 sampel, total penjumlahan dari subwacana ditambah satu wacana keseluruhan ada 420 jawaban. Total penjumlahan subwacana 1 ada $82(97,6 \%)$ menggunakan penalaran yang bersifat induktif, $2(2,4 \%)$ diantaranya merupakan penalaran yang bersifat deduktif, dan 0 jawaban yang tidak teridentifikasi. Total penjumlahan subwacana 2 ada 78 $(92,9 \%)$ menggunakan penalaran yang bersifat induktif, $5(5,9 \%)$ diantaranya merupakan penalaran yang bersifat deduktif, dan $1(1,2 \%)$ jawaban yang tidak teridentifikasi. Total penjumlahan subwacana 3 ada $12(14,3 \%)$ menggunakan penalaran yang bersifat induktif, $68(80,9 \%)$ diantaranya merupakan penalaran yang bersifat deduktif, dan $4(4,8 \%)$ jawaban yang tidak teridentifikasi.Total penjumlahan subwacana 4 ada $45(53,6 \%)$ menggunakan penalaran yang bersifat induktif, $32(38,1 \%)$ diantaranya merupakan penalaran yang bersifat deduktif, dan $7(8,3 \%)$ jawaban yang tidak teridentifikasi. Sedangkan jumlah wacana yang merupakan jawaban untuk subwacana 1, 2, 3 dan 4 ada 17 (20,2\%) menggunakan penalaran yang bersifat induktif, $59(70,2 \%)$ diantaranya merupakan penalaran yang bersifat deduktif, dan $8(9,5)$ jawaban yang tidak teridentifikasi.

Jumlah keseluruhan subwacana 1, 2, 3 dan 4 jawaban ditambah satu wacana ada 420 jawaban yang terdiri dari $234(55,7 \%)$ diantaranya merupakan kesimpulan yang bersifat induktif, $166(39,5 \%)$ diantaranya merupakan kesimpulan yang bersifat deduktif, $20(23,8 \%)$ diantaranya merupakan jawaban yang tidak teridentifikasi.

Hasil wawancara dengan guru kelas atau guru pendamping mengatakan bahwa siswa memiliki penalaran yang kurang bagus wacana argumentasi. Siswa kurang bisa memahami makna dan isi dari teks yang diberikan sehingga ketika siswa harus menarik kesimpulan wacana argumentasi siswa masih kurang paham. Siswa lebih memahami pada hal-hal yang bersifat khusus dan berakhir pada hal-hal yang bersifat umum sehingga siswa lebih cenderung menggunakan penalaran 
induktif dibanding dengan penalaran deduktif..

Begitu juga hasil wawancara dengan beberapa siswa, mereka mengatakan bahwa mereka penalaran mereka kurang pada wacana argumentasi yang diberikan apalagi harus memberikan penalaran yang bersifat induktif dan deduktif. Sehingga kesimpulan yang diberikan kurang sesuai dengan yang diharapkan karena penaralaran siswa yang masih rendah. Pemahaman siswa terhadap penalaran induktif dan deduktif juga masih kurang, sehingga siswa sulit untuk menentukan kesimpulan yang bersifat induktif atau bersifat deduktif yang telah siswa buat.

Hasil penelitian ini sesuai dengan hasil penelitian yang dilakukan oleh Wagino (1998) mengkategorikan kemampuan menulis eksposisi siswa yang ditelitinya. Populasi penelitian terdiri dari para siswa di tiga SMA, yaitu SMA Sanjaya, SMA De Britto, dan SMA Santi Dharma. Berdasarkan temuannya, kemampuan menulis ekspositoris para siswa dapat diurutkan sebagai berikut : siswa kelas III A $A_{2}$, SMA Sanjaya baik, siswa kelas III A $A_{2}$, SMA De Britto cukup, dan siswa kelas III $A_{2}$, dan III A $A_{3}$, SMA Santi Dharma kurang. Sedangkan hasil penelitian Linawati (2001) yang meneliti tentang kemampuana menulis narasi Bahasa Indonesia yang bahasa pertamanya bahasa Jawa dan siswa yang bahasa pertamanya bahasa Indonesia. Hasil penelitiannya menunjukkan bahwa kemampuan menulis karangan narasi Bahasa Indonesia siswa Kelas IV, V, dan VI SD masih kurang yang bahasa pertamanya bahasa Indonesia.

Berdasarkan data di atas dapat disimpulkan bahwa sebagian besar siswa Kelas XI SMU Ign. Slamet Riyadi dan SMU Budiwarman Tahun Ajaran 2019/2020 menggunakan penalaran induktif (234 jawaban) dalam menarik kesimpulan. Perbandingan antara penalaran induktif dengan penalaran deduktif tidak terlalu jauh. Sementara perbandingan antara penalaran deduktif dengan jawaban yang tidak teridentifikasi cukup mencolok. Hal ini menunjukkan bahwa hanya sebagian kecil siswa yang memberikan jawaban yang tidak teridentifikasi sehingga dapat disimpulkan bahwa siswa Kelas XI SMU Ign. Slamet Riyadi dan SMU Budiwarman Tahun Ajaran 2019/2020 sudah memahami pemakaian bahasa dan penalaran dalam menarik kesimpulan wacana argumentasi.

Jadi, dapat disimpulkan bahwa pemakaian bahasa dan penalaran dalam menarik kesimpulan wacana argumentasi pada siswa Kelas XI SMU Ign. Slamet Riyadi dan SMU Budiwarman Tahun Ajaran 2019/2020 sudah baik setelah dilakukan dua kali pengujian. Pada pemakaian bahasa sudah termasuk cukup baik dan setelah dilakukan pengujian kedua siswa telah memahami pemakaian bahasa sebagai alat untuk menarik kesimpulan wacana argumentasi dan hasil pengujiannya sudah baik. Begitu juga pada penalaran bahasa setelah dilakukan dua kali pengujian penalaran siswa sudah baik.

Jumlah keseluruhan subwacana 1, 2, 3 dan 4 jawaban ditambah satu wacana ada 420 jawaban yang terdiri dari $234(55,7 \%)$ diantaranya merupakan kesimpulan yang bersifat induktif, $166(39,5 \%)$ diantaranya merupakan kesimpulan yang bersifat deduktif, $20(23,8 \%)$ diantaranya merupakan jawaban yang tidak teridentifikasi.

\section{SIMPULAN}

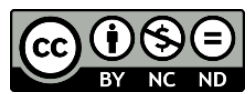

Creative Commons Attribution-NonCommercial-NoDerivatives 4.0 International License 
Adapun simpulan dari penelitian ini yaitu Pemakaian bahasa sebagai alat untuk menarik kesimpulan wacana argumentasi pada siswa Kelas XI Semester II SMU Ign. Slamet Riyadi, SMU Budiwarman dan SMU Pangudi Rahayu Tahun Ajaran 2019/2020 termasuk dalam kategori cukup baik. Sebagian siswa masih memberikan jawaban dengan bahasa yang tidak tersusun dengan baik sehingga jawaban-jawabannya kurang jelas dan tidak sesuai dengan harapan peneliti. Penggunaan penalaran dalam menarik kesimpulan wacana argumentasi sebagian besar siswa menggunakan penalaran induktif dalam menarik kesimpulan. Perbandingan antara siswa yang menggunakan penalaran induktif dengan penalaran deduktif tidak terlalu jauh. Sementara perbandingan antara penalaran deduktif dengan jawaban yang tidak teridentifikasi cukup mencolok. Hal ini menunjukkan bahwa siswa Kelas XI SMU Ign. Slamet Riyadi, SMU Budiwarman, dan SMU Pangudi Rahayu Tahun Ajaran 2019/2020 sudah memiliki penalaran yang baik dalam menarik kesimpulan wacana argumentasi.

Implikasi dari penelitian ini adalah penyelenggaraan pembelajaran bahasa Indonesia, khususnya pemakaian bahasa dan penalaran sebagai alat untuk menarik kesimpulan wacana argumentasi dapat terus dilakukan karena pembelajaran ini dapat meningkatkan minat dan motivasi siswa, dapat meningkatkan kreativitas, keaktifan dan keterlibatan siswa dalam proses belajar mengajar bahasa Indonesia. Siswa menjadi lebih baik dalam pemakaian bahasa dan penalaran bahasa yang siswa miliki juga bisa menjadi semakin meningkat. Hal ini mengimplikasikan bahwa tindakan tersebut dapat berpotensi menjadi alternatif variasi teknik pembelajaran bagi guru bahasa Indonesia atau dapat juga dikembangkan dan disebarkan kepada guru-guru di bidang studi lainnya.

Bertitik tolak dari hasil penelitian tersebut, peneliti ingin menyampaikan saran bagi guru pengampu bidang studi Bahasa dan Sastra Indonesia untuk lebih membekali diri dengan penguasaan materi yang baik, metode pembelajaran dan strategi mengajar yang tepat. Selain itu guru juga harus mengoleksi berbagai jenis wacana dari berbagai sumber yang ada dan nantinya dapat dipakai sebagai alat atau pun materi pembelajaran. Guru juga diharapkan mampu membangkitkan minat dan motivasi siswa terhadap materi yang diajarkan khususnya membaca atau menyimpulkan. Bagi Peneliti Lain, yaitu: Pengambilan subjek penelitian dan sampel penelitian dapat diperluas pada kelas I dan III karena karakteristik pembelajaran tiap jenjang pendidikan sangat khas dan menggunakan metode spiral (tingkat pemahaman dari yang mudah berangsur-angsur menuju ke yang sulit); Penelitian dapat dilanjutkan pada pemakaiana bahasa dan penalaran sebagai alat untuk menarik kesimpulan wacana narasi, persuasi, deskripsi dan eksposisi. Hal ini dimaksudkan supaya pemakaian bahasa sebagai alat untuk menarik kesimpulan wacana lengkap dan berkesinambungan.

\section{DAFTAR PUSTAKA}

Akhadiah, S., Arsjad, M.G., Ridwan, S. H. (2012). Pembinaan kemampuan menulis bahasa Indonesia. Jakarta: Erlangga. 
Haryono, A., \& Tanujaya, B. (2018). Profil kemampuan penalaran induktif matematika mahasiswa pendidikan matematika UNIPA ditinjau dari gaya belajar. Journal of Honai Math, 1(2), 127-138.

Hetifah, S. J., \& Sumarto. (2003). Inovasi, partisipasi dan good governance. Jakarta: Yayasan Obor Indonesia.

Kartodirdjo, S. (2014). Pengantar sejarah Indonesia baru: Sejarah pergerakan nasional dari kolonialisme sampai nasionalisme. Jilid 2. Jakarta: Gramedia Pustaka Utama.

Kemendikbud. (2013). Kerangka dasar kurikulum 2013. Jakarta: Kementerian Pendidikan dan Kebudayaan Direktorat Jenderal Pendidikan Dasar.

Keraf, G. (2010). Argumentasi dan narasi. Jakarta. Gramedia.

Poerwadarminta, W. J. S. (2006). Kamus Umum Bahasa Indonesia, Edisi III, Cet. 3. Jakarta: Balai Pustaka.

Purnama, D. (2010). Cermat memilih sekolah menengah yang tepat. Jakarta: Gagasmedia.

Santrock, J. W. (2009). Psikologi pendidikan Edisi 3 Buku 2. Jakarta: Salemba Humanika.

Shadiq. F. (2004). Penalaran, Pemecahan masalah dan komunikasi dalam pembelajaran matematika. Depdiknas Dirjen Dikdasmen PPPG Matematika, Yogyakarta.

Soekardjo. (1999). Logika dasar. Jakarta: Gramedia.

Sugiyono. (2017). Metode penelitian kuantitatif, kualitatif, dan R\&D. Bandung: CV. Alfabeta.

Sujanto. C. (1998). Ketrampilan berbahasa, membaca-menulis-berbicara untuk mata kuliah dasar umum bahasa Indonesia. Jakarta: Depdikbud.

Suliyanto (2006). Metode riset bisnis. Yogyakarta: Andi.

Sumarmo, U. (2010). Berpikir dan disposisi matematik dalam pembelajaran matematika. Bandung: FPMIPA UPI.

Tarigan, H.G. (2008). Membaca sebagai suatu keterampilan berbahasa. Bandung. Angkasa.

Undang-Undang No. 20 Tahun 2003 tentang Sistem Pendidikan Nasional.

Winkel. (2012). Psikologi pengajaran. Yogyakarta: Media Abadi. 